\title{
Intraspecific and interspecific polyploidy of Brazilian species of the genus Inga (Leguminosae: Mimosoideae)
}

\author{
M.F. Figueiredo ${ }^{1}$, R.L.A. Bruno ${ }^{2}$, A.E. Barros e Silva ${ }^{2}$, S. Nascimento ${ }^{2}$, \\ I.G. Oliveira ${ }^{2}$ and L.P. Felix ${ }^{2}$ \\ ${ }^{1}$ Departamento de Biologia, Universidade do Vale do Acaraú, \\ Sobral, CE, Brasil \\ ${ }^{2}$ Laboratório de Citogenética Vegetal, Departamento de Biologia, \\ Universidade Federal da Paraíba, Campus II, Areia, PB, Brasil \\ Corresponding autor: L.P. Felix \\ E-mail: 1pfelix@cca.ufpb.br
}

Genet. Mol. Res. 13 (2): 3395-3403 (2014)

Received August 23, 2012

Accepted May 15, 2013

Published April 29, 2014

DOI http://dx.doi.org/10.4238/2014.April.29.18

\begin{abstract}
We investigated the karyotypes of 13 species of six sections of the genus Inga (Leguminosae-Mimosoideae) from Brazil. We used conventional Giemsa staining to identify numerical chromosomal variations and looked for karyotypic evolutionary patterns. The karyotypes generally had small chromosomes, varying from metacentric to submetacentric, with a basic number $\mathrm{x}=13$. Nine of the species showed $2 \mathrm{n}=2 \mathrm{x}=26$ (I. thibaudiana, I. cayennensis, $I$. ingoides, I. edulis, I. vera, I. subnuda, I. striata, I. bollandii, and Inga $\mathrm{sp}$ ), while $2 \mathrm{n}=4 \mathrm{x}=52$ was seen in a population of Inga cylindrical and of $I$. capitata, and in five populations of $I$. laurina. Additionally, $2 \mathrm{n}=$ $8 \mathrm{x}=104$ was observed in a population of $I$. cayennensis. Eight of these counts were new, while the counts of $2 \mathrm{n}=52$ for I. laurina and $2 \mathrm{n}=26$ for I. marginata, I. vera, I. subnuda, and I. edulis confirmed previous studies. We did not find cytological stability among the sections studied, with occurrence of significant intra- and inter-specific numerical
\end{abstract}


variations. We conclude that polyploidy has played a significant role in karyotypic evolution in this group and that it occurred independently in several sections of the genus.

Key words: Chromosome evolution; Speciation; Mimosa; Basic number

\section{INTRODUCTION}

Inga is the largest genus of species of the tribe Ingeae, which is distinguished basically by their arboreal size, paripinnate leaves with nectar glands located between each pair of leaflets, fleshy and indehiscent fruits with seeds surrounded by a sweetish, fleshy sarcotesta. It is an exclusively neotropical genus, and Brazil is considered one of the main centers of genetic diversity, with nearly 140 species of a total of 300 attributed to the genus (Pennington, 1997).

Within the family Leguminosae, the tribe Ingeae demonstrates the basic number $\mathrm{x}$ $=13$, with evolution through polyploidy, except for the genus Calliandra Benth. (which has $\mathrm{x}=8$ ) (Atchison, 1951; Berger et al., 1958; Turner and Fearing, 1960). The genus Inga has been only poorly studied karyologically, but like other members of the tribe, it has the basic number $\mathrm{x}=13$. The first chromosome counts for the genus were reported by Shibata (1962), who observed $2 \mathrm{n}=26$ in I. spuria Humb. \& Bonpl. ex Willd. (= I. vera.) and in I. edulis. More recently, Hanson (1995) examined a total of 17 species, of which 15 were diploid (with $2 \mathrm{n}=26$ ) and two tetraploid (I. insignis Kunth and I. laurina, with $2 \mathrm{n}=4 \mathrm{x}=52$ ). Similar data were reported by Okamoto (1998) for I. affinis DC. $(2 \mathrm{n}=26)$, I. sessilis (Vell.) Mart. $(2 \mathrm{n}=$ 26), I. laurina (as I. fagifolia G. Don) $(2 \mathrm{n}=52)$, and I. luschnathiana Benth. $(2 \mathrm{n}=52)$. Only the counts for the first two species were formally published, and together with the data from Okamoto's dissertation, a total of 20 species were karyologically analyzed - just $8 \%$ of the genus. Despite the small number of species studied, polyploidy seems to be the main mechanism of chromosome evolution in the genus Inga (with records of tetraploidy in I. laurina, I. insignis, and I. luschnathiana). Although the explosion of diversity in Inga is apparently recent (Richardson et al., 2001), the karyological data available for the genus do not allow us to conclude if these polyploidy events are equally recent. A total of 37 species of Inga (Lewis, 2006) are known from northeastern Brazil, with the great majority of them from the Atlantic Forest (Lewis, 1987; Pennington, 1997), and chromosome counts are available for eight of them (I. edulis, I. heterophylla Willd., I. laurina, I. sertulifera DC., I. subnuda Salzm. ex Benth., I. umbelifera (Vahl) Steud., I. vera, and I. marginata Willd.). This corresponds to $21 \%$ of the species known for the region, and only one species (I. laurina) has been identified as a tetraploid (Hanson, 1995; Okamoto, 1998).

The present study examined chromosomal variability in 13 Brazilian species of the genus Inga (12 of them from the northeastern region of that country), characterizing their karyotype and analyzing their karyotype evolutionary patterns, focusing especially on the numerical chromosome variability in different populations of I. laurina, I. cayennensis, and I. cylindrica.

\section{MATERIAL AND METHODS}

All of the species analyzed were collected in three states in northeastern Brazil (Ceará, Paraíba, and Pernambuco) except Inga marginata Willd., collected in the southern State of Rio 
Grande do Sul. Thirteen species and 27 populations were studied, representing six sections of the genus. Voucher specimens were stored in the Professor Jayme Coelho de Moraes (EAN) Herbarium at Universidade Federal da Paraíba (UFPB). Table 1 lists the species analyzed, according to sections of Pennington (1997), as well the principal field data and their chromosome numbers.

\begin{tabular}{|c|c|c|c|c|}
\hline Taxa & Provenance & Voucher & $\begin{array}{l}\text { Chromosome } \\
\text { number }(2 n)\end{array}$ & $\begin{array}{l}\text { Previous counts }(2 \mathrm{n}) \\
\text { and references }\end{array}$ \\
\hline \multicolumn{5}{|l|}{ Sect. Bourgonia Benth. } \\
\hline Inga cylindrica (Vell.) Mart. & $\begin{array}{l}\text { Brejo da Madre de Deus, Pernambuco } \\
\text { Brejo da Madre de Deus, Pernambuco }\end{array}$ & MFMata 507 & 52 & \\
\hline \multirow[t]{8}{*}{ I. laurina (Sw.) Willd. } & Itapororoca, Paraíba & MFMata 544 & 52 & $\begin{array}{l}52 \text { (Hanson, 1995; } \\
\text { Okamoto, 1998) }\end{array}$ \\
\hline & Itapororoca, Paraíba & LPFelix 12123 & 52 & \\
\hline & Itapororoca, Paraíba & MFMata 747 & 52 & \\
\hline & Recife, Pernambuco & MFMata 749 & 52 & \\
\hline & Bananeiras, Paraíba & MFMata 752 & 52 & \\
\hline & Goiana, Pernambuco & MFMata 744 & 26 & \\
\hline & Miriri, Paraíba & MFMata 746 & 26 & \\
\hline & Pedra de Fogo, Paraíba & MFMata 745 & 26 & \\
\hline I. marginata Willd. & Rio Grande, Rio Grande do Sul & SPitrez s/n & 26 & 26 \\
\hline Inga sp & Dona Inês, Paraíba & KRFXavier, S/N & 26 & \\
\hline \multicolumn{5}{|l|}{ Sect. Psedoinga Benth. } \\
\hline I. capitata Desv. & Bonito, Pernambuco & LPFelix 11.000 & 52 & \\
\hline \multicolumn{5}{|l|}{ Sect. Multijugae (J. Jéon). } \\
\hline \multirow[t]{2}{*}{ I. thibaudiana DC. } & Areia, Paraíba & MFMata 708 & 26 & \\
\hline & Recife, Pernambuco & LPFelix 11.794 & 26 & \\
\hline \multicolumn{5}{|l|}{ Sect. Longiflorae (Benth) T.D. Penn. } \\
\hline \multirow[t]{2}{*}{ I. cayennensis Sagot ex Benth. } & Santa Rita, Paraíba & LPFelix 11.119 & ca.104 & \\
\hline & Mamanguape, Paraíba & LPFelix 12.257 & 26 & \\
\hline \multirow{3}{*}{ I. cayennensis Sagot ex Benth. } & João Pessoa, Paraíba & LPFelix 12.266 & 26 & \\
\hline & Santa Rita, Paraíba & LPFelix 12.256 & 26 & \\
\hline & Santa Rita, Paraíba & LPFelix 12.258 & 26 & \\
\hline \multicolumn{5}{|l|}{ Sect. Inga Benth. } \\
\hline \multirow[t]{3}{*}{ I. edulis Mart. } & Areia, Paraíba & MFMata 720 & 26 & $\begin{array}{l}26 \text { (Federov, 1969; } \\
\text { Hanson, 1995, } \\
\text { Santos et al., 2012) }\end{array}$ \\
\hline & Lucena, Paraíba & MFMata 706 & 26 & \\
\hline & Cabo, Pernambuco & LPFelix S/N & 26 & \\
\hline \multirow[t]{4}{*}{ I. ingoides (Rich.) Willd. } & Areia, Paraíba & MFMata 628 & 26 & \\
\hline & Baturité, Ceará & MFMata 722 & 26 & \\
\hline & Guaramiranga, Ceará & MFMata 717 & 26 & \\
\hline & Areia, Paraíba & MFMata 565 & 26 & \\
\hline \multirow[t]{2}{*}{ I. subnuda Salzm. ex Benth. } & Taquaritinga do Norte, Pernambuco & MFMata 758 & 26 & $\begin{array}{l}\text { 26, } 52 \text { (Hanson, 1995 } \\
\text { Okamoto, 1998) }\end{array}$ \\
\hline & Areia, Paraíba & MFMata 722 & 26 & \\
\hline \multirow[t]{4}{*}{ I. vera Mart. } & Areia, Paraíba & MFMata 520 & 26 & 26 (Okamoto, 1998) \\
\hline & Areia, Paraíba & MFMata 624 & 26 & \\
\hline & Itapororoca, Paraíba & LPFelix 11.396 & 26 & \\
\hline & Camaratuba, Paraíba & MFMata 551 & 26 & \\
\hline \multicolumn{5}{|l|}{ Sect. Tetragonae (Pittier) T.D. Penn. } \\
\hline I. striata Benth. & Areia, Paraíba & MFMata 527 & 26 & \\
\hline \multicolumn{5}{|l|}{ Sect. Vulpinae (Benth.) T.D. Penn. } \\
\hline I. bollandii Sprague \& Sandwith & Guaramiranga, Ceará & MFMata 718 & 26 & \\
\hline
\end{tabular}

The roots tips of germinating seeds were used for mitotic analysis, as well as scions cultivated in plastic pots in the experimental garden of the Plant Cytogenetics Laboratory of the Center of Agrarian Sciences of the Federal University of Paraíba. A minimum of three individuals derived directly from germinating seeds or from scion clippings were used. The 
roots were pre-treated with $0.2 \mu \mathrm{M} 8$-hydroxyquinoline for 20 to $24 \mathrm{~h}$ at approximately $8^{\circ} \mathrm{C}$, fixed in Carnoy's fluid (ethanol:glacial acetic acid, 3:1) for 3 to $20 \mathrm{~h}$ at room temperature, and then stored at $-20^{\circ} \mathrm{C}$ until analyzed.

The slides were prepared according to Guerra and Sousa (2002), in which the roots were washed twice in distilled water for five minutes, hydrolyzed in $5 \mathrm{~N} \mathrm{HCl}$ at room temperature for $20 \mathrm{~min}$, and squashed in $45 \%$ acetic acid on a slide; the slides were then frozen in liquid nitrogen to remove the cover slips, air dried, stained with $2 \%$ Giemsa (Guerra, 1983), and mounted in Entellan. The best cells were photographed with an Olympus D-54 digital camera adapted to Olympus BX41 microscope and processed using the Corel Photo Paint program.

\section{RESULTS}

All the species demonstrated semi-reticulate interphase nuclei with chromocenters of variable forms and numbers; the prophase condensation pattern was of the proximal type, with pericentometric regions precociously condensed in relation to the chromosome terminals. In spite of the difficulty in obtaining good condensation and chromosome spreading, symmetrical karyotypes with metacentric and submetacentric chromosomes predominated, with a gradual reduction in the size of the chromosomes. Variation in ploidy level was observed between species of the same section, between different sections, and between different populations of the same species.

In the section Bourgonia, $2 \mathrm{n}=52$ was observed (Figure 1A) in a population of $I$. cylindrica from Biturí, and $2 \mathrm{n}=26$ (Figure 1B) was observed in another population from Cavalo Russo, both from the municipality of Brejo da Madre de Deus, Pernambuco State. Polyploid cytotypes, with $2 \mathrm{n}=52$, were also observed in I. laurina from five populations from Paraíba and Pernambuco States (Figure 1C), while $2 \mathrm{n}=26$ was observed in four other populations from these states (Figure 1D). Plants with the cytotype $2 \mathrm{n}=52$ were found to be slightly larger overall, and they also produced larger fruits in greater quantities. Karyotypes with $2 \mathrm{n}=26$ were observed in only one population of $I$. marginata Willd. (Figure 1E) and Inga sp (Figure 1F) - a new species of this section from Paraíba (Garcia, 1998). The only population of I. capitata (section Pseudoinga) studied showed $2 n=52$ in all individuals (Figure 1G).

In the section Multijugae, I. thibaudiana had $2 \mathrm{n}=26$ (Figure $1 \mathrm{H}$ ) in the Pernambuco and Paraíba populations, while $2 \mathrm{n}=104$ was observed in all individuals of $I$. cayennensis from a single population from Santa Rita, Paraíba State (Figure 2A), and $2 \mathrm{n}=26$ in four other populations from Mamanguape, Santa Rita and João Pessoa (Figure 2B). Cells of the cytotype $2 \mathrm{n}=104$ (presumably an octoploid based on $\mathrm{x}=13$ ) were observed to have more numerous chromocenters and apparently smaller chromosomes compared to the diploid cytotype, probably due to a proximal condensation pattern which did not allow the visualization of the distal portions of the chromosome arms (Figure 2A and B). No differences in the size of the fruits, leaves, or flowers between the diploid and octoploid populations were noted in herbarium specimens of I. cayennensis. On the other hand, numerical variations were not seen in the Section Inga, with $2 \mathrm{n}=26$ being seen in I. edulis (Figure 2C), I. ingoides (Figure 2D), I. vera (Figure 2E), and I. subnuda (Figure 2F). Very similar karyotypes were also observed in the sections Tetragonae and Vulpinae, with $2 \mathrm{n}=26$ in I. striata (Figure 2G) and I. bollandii (Figure 2H). 

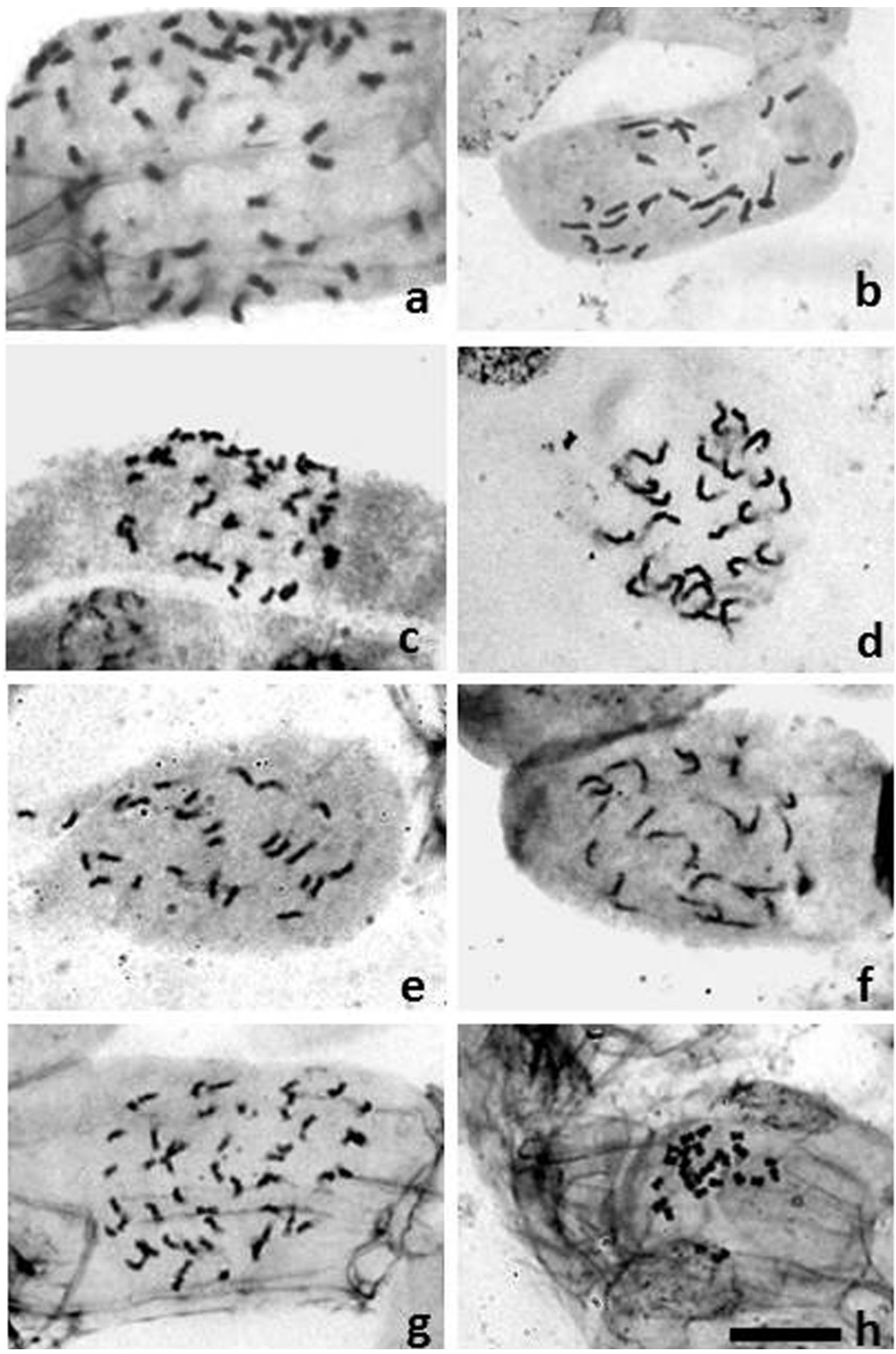

Figure 1. Metaphase and prometaphase chromosomes in species of Inga of the sections Bourgonia (a-f), Pseudoinga (g) and Multijugae (h). Inga cylindrica with $2 \mathrm{n}=52$ (a) and $26(\mathbf{b})$; I. laurina with $2 \mathrm{n}=52$ (c) and 26 (d); I. marginata with $2 \mathrm{n}=26$ (e); Inga $\mathrm{sp}, 2 \mathrm{n}=26(\mathbf{f}) ;$ I. capitata, $2 \mathrm{n}=52(\mathrm{~g})$ and I. thibaudiana, $2 \mathrm{n}=26$ (h). Note in (d) the prophase condensation pattern was of the proximal type. Bar in $\mathbf{h}=10 \mu \mathrm{m}$. 

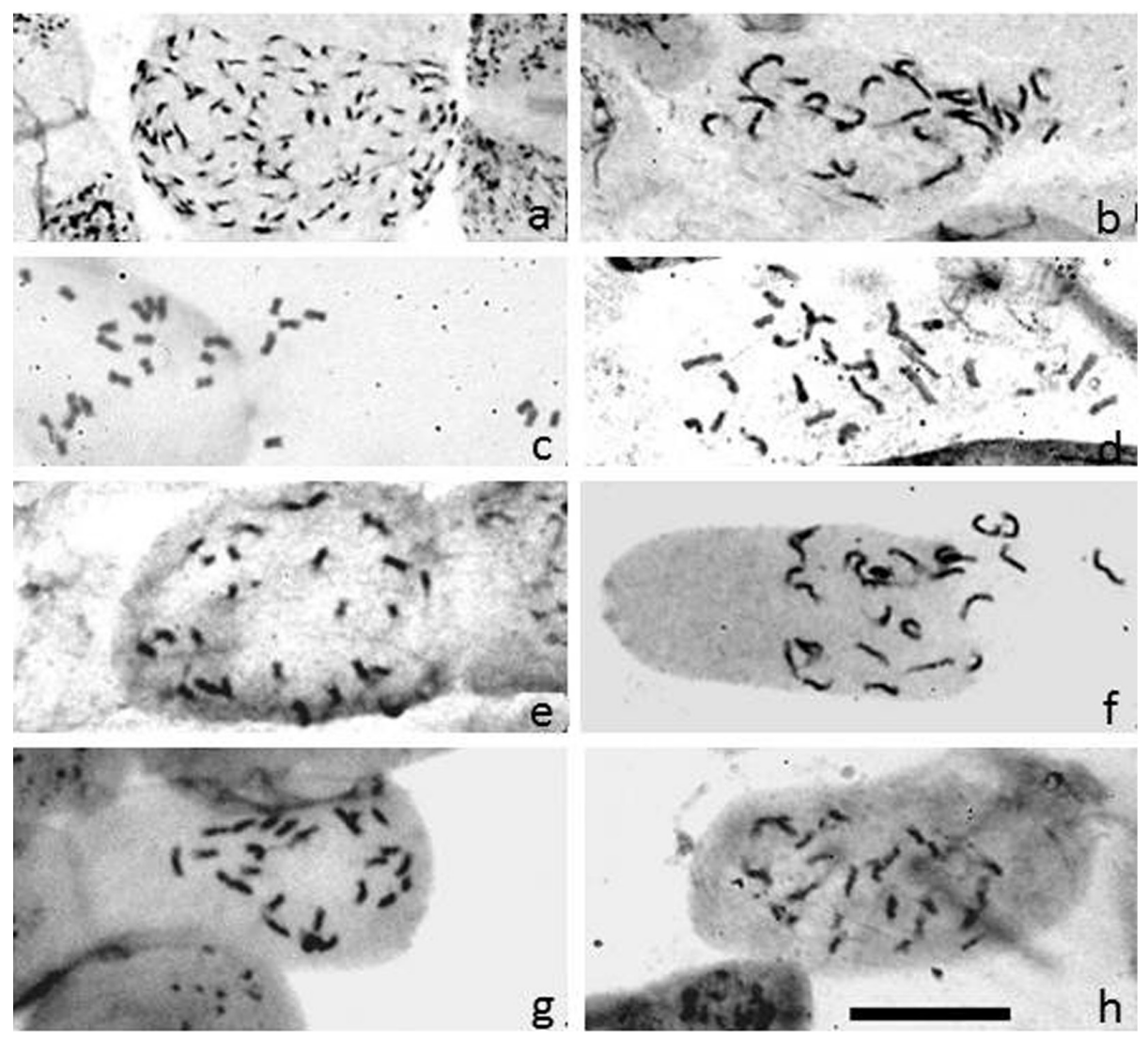

Figure 2. Metaphase and prometaphase chromosomes in species of Inga of the sections Longiflorae (a and b), Inga (c-f), Tetragonae (g) and Vulpina (h). Inga cayennensis with $2 \mathrm{n}=104$ (a) and 26 (b), I. edulis (c), I. ingoides (d), I. vera (e), I. subnuda (f), I. striata (g), and $I$. bollandii, (h) all with $2 \mathrm{n}=26$. Note in a semi-reticulated interphase nuclei. Bar in Figure $\mathbf{h}=10 \mu \mathrm{m}$.

\section{DISCUSSION}

Of the approximately 300 recognized species of the genus Inga (Pennington, 1997), only 20 have previously been karyotypically examined, a number which corresponds to approximately $8 \%$ of the genus. Our data represent an addition of nine other counts (and the partial confirmation of another four, as commented below). Only karyological data referring to chromosome numbers are currently available due to the problem of finding cells with sufficient spreading and condensation to allow a clear identification of the centromere position (Hanson, 1995). Our data in fact confirm this characteristic of the genus, as all of the species analyzed had generally small and difficult to spread chromosomes, especially during metaphase, which resulted in an analysis based mainly on prometaphase chromosomes.

The basic number $\mathrm{x}=13$ suggested for the genus (Shibata, 1962; Hanson, 1995) was confirmed, as well as the previous reports of $2 \mathrm{n}=26$ by Hanson (1995) for I. marginata, I. edulis, and I. subnuda. However, the 2n $=52$ count (Hanson, 1995; Okamoto, 1998) for $I$. 
laurina was confirmed for only five tetraploid populations from Paraíba and Pernambuco. The other four populations of this species examined were diploid, with $2 \mathrm{n}=26$. In these cases, the plants seemed to have distinctly smaller leaves and fruits (Mata, 2009). The analysis of I. subnuda performed by Hanson (1995) agreed with our data, but divergence was noted in relation to the (unpublished) data of Okamoto (1998) for I. luschnathiana Benth. This species was recombined by Pennington (1997) with I. subnuda subsp. luschnathiana due to its broadly winged rachis (in addition to other floral and fruit characteristics) and its exclusive occurrence in southern and southeastern Brazil. Although there are no taxonomic descriptions available of the material studied by Okamoto (1998), the morphologic differentiation made by Pennington (1997), allied to the fact that the subspecies has a distinct area of distribution (southeastern Brazil), indicates that the occurrence of a southern polyploid cytotype supports the maintenance of the subspecies luschnathiana.

Intraspecific polyploidy is a relatively rare phenomenon in Leguminosae-Mimosoideae, having been reported for some populations of Leucaena palida and L. tricandra of the tribe Mimoseae (Cardoso et al., 2000; Schifino-Wittmann, 2004), for Vachelia farnesiana of the tribe Acacieae, and for Mimosa setosa var. paludosa (Dahmer et al., 2011). The existence of different ploidy levels among populations of the same species generally defines distinct biological species (Freeman and Herron, 2004), or the formation of local races, geographical races, or polyploid complexes. These cytotypes correspond to subspecies, varieties, or taxonomic species, depending on their regions of occurrence and their morphologic differentiation (Grant, 1989). No overlapping areas of occurrence of the two cytotypes of I. laurina were observed, indicating preferential distribution at the ploidy level. All samples (populations) examined in the Mamanguape River basin in Paraíba State (Jacoca, Macacos, Pioca, and Bananeiras) were tetraploid (with $2 \mathrm{n}=52$ ). This same chromosome number was also observed in the population from Recife (Pernambuco State) and in the counts reported by Hanson (1995) and Okamoto (1998), suggesting that tetraploids are more successful than diploids.

The other intraspecific numerical variations observed in I. cylindrica (Vell.) Mart. (2n $=26,52)$ and in $I$. cayennensis $(2 \mathrm{n}=26,104)$ (from neighboring forest fragments) suggest that polyploidy is the main mechanism of karyotypic evolution in the genus Inga. In this genus, as well as in several others from the tribes Ingeae (Atchison, 1951; Turner and Fearing, 1960), Acacieae (Oballa and Olng'Otie, 1993), and Mimoseae (Cardoso et al., 2000; Schiffino-Withman, 2004), chromosome numbers that are multiples of 13 are more frequent - with the notable exception of the genus Calliandra, which has $\mathrm{x}=8$ (Atchison, 1948; Arce, 1992). Interestingly, in I. cayenensis, the diploid cytotype showed interphase nuclei distinct from octaploid, suggesting that structural changes occurred in the latter. Genome structuring has been considered one of the important mechanisms of long time karyotype differentiation in autopolyploids (Parisod et al., 2010) and probably played a role in the establishment of this cytotype.

Although the total number of published chromosome counts for the genus Inga represents only $9.33 \%$ of the total of species, there does not appear to be a tendency for stability in ploidy levels of the sections studied. Even in Pennington's (1997) section of Inga, where all four species examined in the present study were diploid with $2 n=26$, Hanson (1995) reported that $I$. insignis was tetraploid, with $2 \mathrm{n}=52$. In the sections of Inga that have had more than one species analyzed, variations in intra- and interspecific ploidy levels have been observed. The nature of this polyploidy, however, is currently unknown, and the available data do not allow us to determine if these species are autopolyploids or allopolyploids. Neopolyploids tend 
to share the same geographical area with their ancestral diploids (Ehrendorfer, 1980; Guerra, 2008). In the case of Inga, the species showing intraspecific polyploidy (independent of being autopolyploids or allopolyploids) then seem to be of recent origin because they share the same geographical area with other diploid populations. Diploid and tetraploid cytotypes are reproductively isolated, and polyploidy certainly played an important role in the diversification of this genus.

Due to the fact that the species of Inga are difficult to delimit and have only small numbers of base substitutions in their chloroplast and nuclear DNA and that their phylogeny has not been well resolved, the time of diversification of the current species of Inga has been estimated at between 2 and 13.4 million years (Richardson et al., 2001). Cases such as $I$. cylindrica and I. cayennensis, where no habitat discontinuity between diploid and polyploid populations has been observed and they share practically the same vegetation fragments, support the hypothesis of a recent origin. In this case, the reproductive isolation barriers created by the appearance of neopolyploids and cytotypes better adapted to particular environments would certainly contribute to the rapid diversification of the genus. Several levels of speciation that have been influenced by polyploidy seem to have occurred in the present sample. $I$. laurina has a surviving ancestral diploid stock that is geographically very near to the diploid populations, and they are not clearly morphologically differentiated and thus seem to be in an active process of speciation. But, in the case of I. subnuda (with $2 \mathrm{n}=26$ ) and I. subnuda subsp luschnatiana (Benth.) T.D. Penn. (with 2n = 52) (Okamoto, 1998), speciation was followed by geographical isolation and greater morphological and ecological differentiation. Some authors such as Bentham (1876) and Lewis (1987) considered them to be distinct species.

As such, polyploidy appears to be the main mechanism of karyotypic evolution in the genus Inga, and has an important role in the diversification of this taxon. However, these ploidy variations do not seem to have any relation to the sections proposed by Pennington (1997), corroborating the idea already advanced by this and other authors (see, for example, Garcia, 1998) that they represent artificial groups.

\section{ACKNOWLEDGMENTS}

Research supported by FUNCAP (Fundação Cearense de Amparo à Pesquisa), CNPq (Conselho Nacional de Desenvolvimento Científico e Tecnológico), CAPES (Coordenação de Aperfeiçoamento de Pessoal de Nível Superior), and Universidade Estadual do Vale do Acaraú (UVA).

\section{REFERENCES}

Arce MLR (1992). New chromosome counts in neotropical Albizia, Harvardia and Pithecellobium, and a new combination for Albizia (Leguminosae-Momosoideae-Ingeae). Bot. J. Linn. Soc. 108: 269-274.

Atchison E (1948). Studies in the Leguminosae. II. Cytogeography of Acacia (Tourn.) L. Am. J. Bot. 35: 651-655.

Atchison E (1951). Studies in the Leguminosae VI. Chromosome number among tropical wood species. Am. J. Bot. 38: 538-547.

Bentham G (1876). Leguminosae Mimosoideae. In: Flora Brasiliensis (Martius CFP and Eichler AG, eds.). Regia C. Wolf et Filius, 458-500.

Berger CA, Witkus ER and Mcmahon RM (1958). Cytotaxonomic studies in the Leguminosae. Bull. Torrey Bot. Club 85: 405-415.

Cardoso MB, Schifino-Wittimann MT and Zanettini MHB (2000). Taxonomic and evolutionary implications of 
intraspecific variability in chromosome numbers of species of Leucaena Benth. (Leguminosae). Bot. J. Linn. Soc. 134: 549-556.

Dahmer N, Simon MF, Schifino-Wittmann MT, Hughes CE, et al. (2011). Chromosome numbers in the genus Mimosa L.: Cytotaxonomic and evolutionary implications. Plant Syst. Evol. 3: 211-220.

Ehrendorfer F (1980). Polyploidy: Biological Relevance In: Polyploidy and Distribution (Lewis WH, ed.). Plenum Press, New York, 45-60.

Freeman S and Herron JC (2004). Evolutionary Analysis. Pearson Education, London.

Garcia FCP (1998). Relações Sistemáticas e Fitogeográficas do Gênero Inga Miller (Leguminosae, Mimosoideae, Ingeae) nas Florestas da Costa Sul e Sudeste do Brasil. Doctoral thesis. Universidade Estadual Paulista, Rio Claro.

Grant V (1989). Especiación Vegetal. Noriega, México.

Guerra M (1983). O uso do Giemsa na citogenética vegetal - comparação entre a coloração simples e o bandeamento. Cienc. Cult. 35: 190-193.

Guerra M (2008). Chromosome numbers in plant cytotaxonomy: concepts and implications. Cytogenet. Genome Res. 120: 339-350.

Guerra M and Souza MJ (2002). Como Observar Cromossomos: Um Guia de Técnicas em Citogenética Vegetal, Animal e Humana. FUNPEC, Ribeirão Preto.

Hanson L (1995). Some new chromosome counts in the genus Inga (Leguminosae: Mimosoideae). Kew Bull. 50: 801-804.

Lewis GP (1987). Legumes of Bahia. Royal Botanic Gardens, Kew.

Lewis GP (2006). Checklist das Plantas do Nordeste Brasileiro: Angiospermas e Gymnospermas. In: Leguminosae Subfam. Mimosoideae (Barbosa MRV, Sothers C, Mayo S, Gamarra-Rojas CFL, et al., eds.). Ministério de Ciência e Tecnologia, Brasília, 86-90.

Mata MF (2009). O Gênero Inga (Leguminosae, Mimosoideae) no Nordeste do Brasil: Citogenética, Taxonomia e Tecnologia de Semente. Doctoral thesis. Universidade Federal da Paraíba, Areia.

Oballa PO and Olng'Otie PAS (1993). Chromosome numbers in two African Acacia species. Kew Bull. 49: 107-113.

Okamoto JM (1998). Ecofisiologia da Germinação e do Metabolismo Respiratório de Quatro Espécies do Gênero Inga Mill. (Mimosaceae) Submetidas à Hipoxia e Anoxia. Master's thesis. Universidade Estadual de Campinas, Campinas.

Parisod C, Holderegger R and Brochmann C (2010). Evolutionary consequences of autopolyploidy. New Phytol. 186: 5-17.

Pennington TD (1997). The Genus Inga. Royal Botanic Gardens, Kew.

Richardson JE, Pennington RT, Pennington TD and Hollingsworth PM (2001). Rapid diversification of a species-rich genus of neotropical rain forest trees. Science 293: 2242-2245.

Santos EC, Carvalho R, Almeida EM and Felix LP (2012). Chromosome number variation and evolution in Neotropical Leguminoseae (Mimosoideae) from northeastern Brazil. Genet. Mol. Res. 11: 2451-2475.

Schifino-Wittmann MT (2004). Citogenética do gênero Leucaena Benth. Cienc. Rural 34: 309-324.

Shibata K (1962). Cytological studies on some wild and cultivated plants of Colômbia. II. Species of Mimosaceae and Galegeae. Jpn. J. Genet. 37: 410.

Turner BL and Fearing OS (1960). Chromosome numbers in the Leguminosae. III. Species of the Southwestern United States and Mexico. Am. J. Bot. 47: 603-608. 